\title{
Hubungan antara Mindful Parenting dengan Gaya Pengasuhan pada Ibu yang Memiliki Anak Usia 3-6 Tahun
}

\section{Correlation between Mindful Parenting and Mother's Parenting Style of 3-6 Years Old Children}

\author{
Widya Saraswati ${ }^{1}$, Zulfa Febriani ${ }^{2}$ \\ ${ }^{1}$ Fakultas Psikologi Universitas YARSI, Jl. Let. Jend. Soeprapto, Jakarta, 10510 \\ Email: zulfa.edu@gmail.com
}

KATA KUNCI
KEYWORDS

ABSTRAK

ABSTRACT
Mindful Parenting, Pola Asuh, Ibu, Anak Usia 3-6

Mindful Parenting, Mother's Parenting Styles, early childhood (3-6 years old children)

Anak usia dini (3-6 tahun) berada dalam tahap mengembangkan inisiatif sehingga umumnya tampil dengan penuh energi dan eksplorasi. Hal ini dapat menguras energi emosional ibu sebagai pengasuh utama. Untuk itu, ibu perlu terampil mengelola kondisi emosional dengan tetap merespon anak secara baik dan memerhatikan kebutuhan anak untuk memahami konsteks sosial. Mindfulness dalam pengasuhan (mindful parenting) menerapkan kesadaran penuh dalam konteks pengasuhan yang sedang berlangsung antara ibu dengan anak, sehingga memfasilitasi ibu untuk sabar, menerima, sekaligus memanfaatkan moment yang ada untuk membangun interaksi sehingga dianggap dapat membangun gaya pengasuhan yang positif. Tujuan penelitian ini adalah untuk mengetahui hubungan antara mindful parenting dengan pola asuh pada ibu yang memiliki anak usia 3-6 tahun. Partisipan dalam penelitian ini berjumlah 101 ibu yang dipilih secara incidental di daerah DKI Jakarta. Penelitian ini menggunakan alat ukur Mindfulness in Parenting Questionnaire (MIPQ) dan The Parenting Styles and Dimensions Questionnaire (PSDQ). Data diolah dengan korelasi Pearson Product Moment. Hasil penelitian menyatakan bahwa, terdapat hubungan positif yang siginifikan antara mindful parenting dengan tipe pola asuh authoritative $(\mathrm{r}=0,608 ; \mathrm{p}=0,000<0,05)$, dan hubungan negative yang signifikan dengan pola asuh authoritarian $(\mathrm{r}=-0,278 ; \mathrm{p}=0,005<0,05)$. Sementara, tidak terdapat hubungan yang signifikan antara mindful parenting dengan tipe pola asuh permissive $(\mathrm{r}=-0,171 ; \mathrm{p}=0,087>0,05)$. Hal ini menunjukkan bahwa semakin seorang ibu memiliki karakter atau kemampuan pengasuhan yang berkesadaran maka akan semakin memiliki pola asuh yang autorithative. Kesimpulan penelitian perlu mempertimbangkan kondisi sampel yang kurang beragam secara sosiodemografis.

Early childhood (3-6 years) are in the stage of developing initiatives so that they are generally full of energy and exploration. This can drain the emotional energy of the mother as the primary caregiver. For this reason, mothers should be able in managing emotional conditions while responding adequately to children and paying attention to their needs of understanding the social context. Mindfulness in parenting (mindful parenting) applies full awareness in the context of ongoing interaction between mother and child, thereby facilitating the mother to be patient, accepting, while taking ongoing moment to build positive interaction with the children. Mindful parenting enables mothers to build a positive parenting style. The research aimed to know whether significant relationship between mindful parenting and parenting style in mothers of 3-6 years old children. The participants were 101 mothers spread out across Jakarta. The data was collected by Mindfulness in Parenting Questionnaire (MIPO) and The Parenting Styles and Dimensions Questionnaire (PSDQ). Data was analysed by Pearson's Product Moment. According to the study, there were significant positive correlation between mindful parenting with authoritative parenting style $(r=0,608 ; p=0,000<0$, 05), significant negative relation with authoritarian parenting style $(r=-0,278 ; p=0,005<0$, 05), but no significant relationship with permissive parenting style $(r=-0,171 ; p=0,087>0$, 05). In 
conclusion, the more the mother interacts with the child in full awareness, the higher the mother able to practice authoritative parenting style. The result should be generalized with caution based on sample socio-demographic differences.

\section{PENDAHULUAN}

Anak usia dini mengalami masa perkembangan otak anak pada fase optimal untuk mempersiapkan anak memperoleh keterampilan dan pembelajaran di usia sekolah sampai kehidupan dewasa nanti (Black, Walker, Fernald, Andersen, Digirolama, Lu, dkk. 2016). Pada masa usia dini ini pula menurut Erikson (dalam Santrock, 2015) anak mengembangkan inisiatif untuk mengeksplorasi dunianya, mencontoh orang-orang terdekatnya, menjadi tahu sebab dan akibat serta tata aturan di sekitarnya, mengembangkan kemampuan mengatur dirinya serta keterampilan kesiapan dalam bersekolah (seperti mentaati peraturan, mengidentifikasi huruf, dan lain sebagainya). Anak memiliki energi yang besar sehingga mampu mengeksplorasi area baru bahkan berbahaya sekalipun untuk mengembangkan inisiatif mereka.

Karakter perkembangan anak usia dini tersebut memberikan tantangan tersendiri khususnya bagi ibu yang biasanya merupakan pengasuh utama. mengatakan bahwa perilaku anak dan aktivitas pengasuhan sehari-hari terutama ketika anak berusia dini dapat mengakibatkan kelelahan dan menguras energi psikis. Ketika seorang ibu mengalami kondisi emosional seperti ini, ia dapat menjadi kurang peka dan reflektif terhadap perilaku anak bahkan bereaksi secara emosional sehingga tidak menyadari reaksinya memaksa anak untuk tetap berada dalam kontrol. Ia pun dapat menerapkan gaya pengasuhan yang negatif (William dan Wahler, 2010). Padahal salah satu faktor yang penting dalam tumbuh kembang anak usia dini adalah nurturing care, yaitu pengasuhan yang responsif, mendukung secara emosional, dan sesuai dengan kebutuhan perkembangan anak (Black \& Aboud, dalam Black, Walker, dkk. 2016).

Kondisi pengasuhan nurturing care sebagaimana yang dinyatakan oleh Baumrind (dalam Sigelman \& Rider 2002) bahwa orang tua atau pengasuh utama perlu memiliki responsivitas dan memberikan tuntutan yang seimbang terhadap anak-anaknya agar dapat berkembang menjadi pribadi yang utuh sekaligus juga menyesuaikan diri dalam tatanan masyarakat. Responsivitas atau disebut juga acceptance ditunjukkan oleh orang tua yang merespon dengan tepat interaksi dan kebutuhan anak, memberikan dukungan dan kehangatan terhadap anak. Sementara tuntutan yang seimbang merupakan dimensi demandingeness yang ditunjukkan oleh orang tua atau pengasuh utama, seperti membatasi tingkah laku anak, membuat aturan agar anak mematuhi, sekaligus dapat bersikap tegas.

Baumrind (dalam Santrock, 2015) mengatakan bahwa bagaimana orangtua atau pengasuh utama mengkombinasikan responsivitas dengan demandingness akan menghasilkan salah satu dari ketiga tipe pola asuh. Pola asuh yang pertama adalah authoritative. Pola asuh yang kedua adalah authoritarian dan pola asuh yang ketiga adalah permissive. Baumrind (dalam Robinson, Mandleco, Olsen, \& Hart, 2001) menjelaskan bahwa pada tipe pola asuh authoritative, orangtua memperhatikan dan menghargai kebebasan anak, namun kebebasan itu terdapat aturannya dimana anak tetap di arahkan dengan bimbingan yang penuh dari orangtua. Pada tipe pola asuh authoritarian, sikap orangtua mendidik anak dengan membuat aturan-aturan dan batasan - batasan yang sudah diterapkan oleh orangtua tanpa adanya persetujuan terlebih dahulu dengan anak. Pada pola asuh permissive, sikap orangtua 
cenderung memberikan kebebasan sesuai dengan apa yang di inginkan oleh anak, akibatnya anak tidak peduli apakah hal yang di inginkannya sesuai dengannya atau tidak. Di antara ketiga pola asuh ini, pola asuh authoritative yang paling sering dianggap pola asuh yang positif karena seringkali dikaitkan dengan perkembangan perilaku anak yang baik.

Meskipun demikian, Grusec dkk. (dalam Santrock, 2015) mengatakan bahwa pengasuhan yang positif memerlukan usaha dan waktu. Kebanyakan para ahli perkembangan anak menyarankan untuk menghadapi perilaku anak dengan dialog, menjelaskan konsekuensi perilaku anak, dan memberi jeda (Santrock, 2015). Hal ini menunjukkan bahwa seorang ibu perlu memiliki kondisi emosional yang stabil dan terkontrol dalam menghadapi perilaku anak usia dini. Kondisi ini sejalan dengan konsep mindfulness yang diterapkan dalam pengasuhan atau mindful parenting. Menurut Kabat-Zinn dan Kabat Zinn (dalam McCaffrey, Reitman, \& Black, 2017), mindful parenting adalah cara atau bentuk pendekatan orangtua yang memberikan perhatian kepada anak dan proses pengasuhan dengan cara menekankan pada apa adanya anak dan dengan intensitas hubungan antara orangtua dengan anak, fokus pada saat ini dan disini, serta melakukan proses pengasuhan tanpa adanya penghakiman.

Bagi seorang ibu dalam interaksi pengasuhan sehari-hari, kemampuan mindful parenting membuat dirinya tidak mudah stres ketika menghadapi anakanak dalam pengasuhannya, lebih dapat menghargai pendapat dan perilaku yang dilakukan oleh anak, dan dapat menjalin hubungan yang harmonis dengan anak (Mubarok, 2016). Ibu yang menggunakan pengasuhan mindful parenting dapat mendorong anak-anak untuk melakukan perilaku yang positif dan konsisten dalam mencegah perilaku bermasalah (Bluth \& Wahler, dalam Mubarok, 2016). Hal ini karena menggunakan mindful parenting dalam berinteraksi dengan anak membantu Ibu untuk berhenti sejenak dan mengubah keadaan kesadaran sehingga dapat merespon anak dengan perhatian pada peristiwa yang saat itu berlangsung serta mempertimbangkan nilai hubungan orang tua dengan anak dalam jangka panjang. Dengan kata lain, mindful parenting memfasilitasi keadaan internal untuk memperbaiki kemampuan menggunakan praktik pengasuhan yang adaptif melalui (1) kesadaran dan fokus perhatian pada saat interaksi pengasuhan berlangsung, (2) penerimaan tanpa penghakiman terhadap perilaku anak, dan (3) kemampuan meregulasi reaktivitas terhadap perilaku anak (Parent, McKee, Mahon, \& Foreh, 2016).

Menurut Singh (dalam William \& Wahler, 2009), jika ibu dapat menyadari dan mengevaluasi gaya pengasuhannya, mengamati dengan penuh kesadaran kaitan antara gaya yang ia terapkan dengan perilaku anaknya, maka ia akan lebih dapat menerapkan gaya pengasuhan yang autoritatif, dan mengurangi penggunaan energi psikis dalam melibatkan anak pada konteks pengasuhannya. Penelitian yang dilakukan oleh Gouveia, Carona, Canavarro, dan Moreira (2016) menunjukkan bahwa seseorang yang memiliki level mindfulness yang baik seringkali dikaitkan dengan level mindful parenting yang lebih baik pula serta gaya pengasuhan yang lebih positif. Mindful parenting pada penelitian tersebut secara langsung menunjukkan korelasi positif dengan gaya pengasuhan tipe authoritative, sementara korelasinya negatif dengan gaya pengasuhan tipe authoritarian dan permissive. Dengan demikian dapat disimpulkan bahwa semakin mampu seorang ibu mengaplikasikan mindful parenting dalam interaksi dengan anak, semakin ibu dapat memiliki gaya pengasuhan yang authoritative. 
Mengingat pentingnya pengasuhan yang utama pada sisi ibu dan pentingnya masa pengasuhan usia 3-6 tahun, maka peneliti tertarik untuk mengetahui hubungan antara mindful parenting dengan gaya pengasuhan pada ibu yang memiliki anak usia 3 hingga 6 tahun. Penelitian ini pun belum banyak dilakukan di Indonesia sementara konteks pengasuhan dapat berbeda berdasarkan ras dan budaya (Steinberg \& Silk, dalam Santrock, 2015). Oleh karena itu, peneliti ingin menguji hipotesis bahwa mindful parenting berkorelasi positif dengan gaya pengasuhan authoritative sementara korelasinya negatif dengan gaya pengasuhan permissive dan authoritarian. Penelitian ini merupakan bagian dari payung penelitian mindfulness pada setting keluarga. Penelitian ini diharapkan dapat memberikan sumbangan terhadap kajian dan penelitian psikologi terkait pola asuh ibu dengan anak usia 3 - 6 tahun dan mindful parenting khususnya di Indonesia.

\section{METODE PENELITIAN}

Variabel yang ingin diteliti adalah mindful parenting dan tipe gaya pengasuhan authoritative, authoritarian, dan permissive. Penelitian ini termasuk dalam pendekatan penelitian kuantitatif dan non eksperimental dengan tipe penelitian korelasional karena ingin mengetahui hubungan antara dua variabel (Sugiyono, 2014). Populasi dalam penelitian ini adalah Ibu yang memiliki anak usia 3-6 tahun di Indonesia. Teknik pengambilan sampel dalam penelitian ini adalah insidental sampling yang mana sampel diambil secara kebetulan bila sesuai dengan kriteria penelitian (Sugiyono, 2014). Peneliti mengambil 101 sampel partisipan di DKI Jakarta karena peneliti menganggap populasi DKI Jakarta cukup beragam dan dapat mewakili gaya pengasuhan yang diteliti. Berdasarkan data demografi pada tabel 1, sebagian besar partisipan $(86,1 \%)$ berada pada kelompok usia dewasa muda (20-40 tahun). Kebanyakan mereka berasal dari suku bangsa Jawa (47,52\%). Sebagian besar mereka juga berasal dari kelas sosial menengah ke atas yang ditunjukkan dengan penghasilan yang berkisar antara 3-7 jt dan pengeluaran sekitar 1-7 juta per bulan. Sebagian besar partisipan $(50,5 \%)$ memiliki latar belakang pendidikan tinggi (D3,S1,S2,S3). Sebagian besar partisipan memiliki anak dengan berjenis kelamin laki-laki (52,5\%).

Tabel 1 : Data Demografi

\begin{tabular}{lcc}
\hline \multicolumn{1}{c}{ Variabel } & Jumlah & Persentase \\
\hline Usia Partisipan (Papalia,2009) & & \\
19-20 Tahun (Remaja Akhir) & 4 & $4,0 \%$ \\
20-40 Tahun (Dewasa Muda) & 87 & $86,1 \%$ \\
40-65 Tahun (Dewasa Tua) & 10 & $9,9 \%$ \\
Suku Bangsa & & \\
Jawa & 48 & $47,52 \%$ \\
Sunda & 22 & $21,78 \%$ \\
Betawi & 14 & $13,86 \%$ \\
Melayu & 7 & $6,9 \%$ \\
Minang & 3 & $2,97 \%$ \\
Batak & 6 & $5,94 \%$ \\
Ambon & 1 & $0,99 \%$ \\
\hline
\end{tabular}




\begin{tabular}{|c|c|c|}
\hline \multirow{2}{*}{$\begin{array}{l}\text { Variabel } \\
\text { Pemasukan }\end{array}$} & \multicolumn{2}{|c|}{ Jumlah Persentase } \\
\hline & & \\
\hline$<1.000 .000$ & 9 & $8,8 \%$ \\
\hline $1.000 .000-3.000 .000$ & 34 & $33,3 \%$ \\
\hline $3.000 .000-7.000 .000$ & 44 & $43,1 \%$ \\
\hline$>7.000 .000$ & 14 & $13,7 \%$ \\
\hline \multicolumn{3}{|l|}{ Pengeluaran } \\
\hline < Rp. 797.724,6 & 0 & $0 \%$ \\
\hline $797.724,6-7.977 .246$ & 87 & $86,1 \%$ \\
\hline$>7.977 .246$ & 14 & $13,9 \%$ \\
\hline \multicolumn{3}{|l|}{ Pendidikan } \\
\hline Pendidikan Dasar (SD,MI,SMP\& MTS) & 8 & $7,9 \%$ \\
\hline Pendidikan Menengah (SMA,MA,SMK,\& MAK) & 42 & $41,6 \%$ \\
\hline Pendidikan Tinggi(D1,D2,D3,D4,S1,S2,S3,Profesi\& Spesialis) & 51 & $50,5 \%$ \\
\hline \multicolumn{3}{|l|}{ Usia Anak } \\
\hline 3 Tahun & 46 & $45,5 \%$ \\
\hline 4 Tahun & 16 & $15,8 \%$ \\
\hline 5 Tahun & 14 & $13,9 \%$ \\
\hline 6 Tahun & 25 & $24,8 \%$ \\
\hline \multicolumn{3}{|l|}{ Jenis Kelamin Anak } \\
\hline $\mathrm{P}$ & 48 & $47,5 \%$ \\
\hline $\mathrm{L}$ & 53 & $52,5 \%$ \\
\hline
\end{tabular}

Alat ukur dalam penelitian ini menggunakan Mindfulness in Parenting Questionnaire (MIPQ) dan The Prenting Style and Dimensions Questionnaire (PSDQ). MIPQ disusun oleh McCaffrey, Reitman dan Black pada tahun 2017. Skala ini terdiri dari 2 dimensi, yaitu mindful discipline dan being in the moment with child. Aitem dalam alat ukur ini berjumlah 28 aitem. Setelah peneliti melakukan alih bahasa dan uji coba, MPIQ memiliki nilai reliabilitas 0,96 dan validitas aitem yang berkisar 0,2-0,8. PSDQ disusun oleh Robinson, Hart dan Roper (2001) yang terdiri dari 2 dimensi, yaitu acceptance dan demangdines. Kedua dimensi dari pola asuh ini membentuk tiga pola asuh diantaranya authoritative, authoritarian dan permissive. PSDQ yang dikembangkan oleh Robinson ini memiliki nilai reliabilitas authoritarian $(\alpha=0,82)$, authoritaritative $(\alpha=0,86)$ dan permissive $(\alpha=0,64)$. Sedangkan untuk nilai validitas dari setiap tipe pola asuhnya yaitu authoritarian $(0,62-0,95)$, authoritative $(0,71-0,97)$ dan permissive $(0,38-0,95)$.

Data pada penelitian ini terdistribusi secara normal berdasarkan Kolmogorov-smirnov Test. Hal ini dapat diketahui dari tabel 2 dimana nilai signifikansi tiap variabel yang melebihi 0,5 (Sugiyono, 2014). Dengan demikian, metode uji kolerasi teknik Pearson product moment digunakan untuk mengetahui apakah terdapat hubungan antar variable dalam sampel yang diambil dari populasi yang telah ditentukan.

Tabel 2. Uji Normalitas

\begin{tabular}{|c|c|c|}
\hline Variabel & Kolmogorov - Smirnov & Sig \\
\hline Authoritative & 0,979 & $0,200 *$ \\
\hline Authoritarian & 0,978 & $0,168 *$ \\
\hline Permissive & 0,982 & $0,190 *$ \\
\hline MIPQ & 0,992 & $0,200^{*}$ \\
\hline
\end{tabular}




\section{ANALISA DAN HASIL}

Penelitian ini bertujuan untuk mengetahui hubungan antara mindful parenting dengan gaya pengasuhan. Hasil korelasi Pearson pada tabel 3 menunjukkan bahwa mindful parenting memiliki hubungan yang positif dengan pola asuh tipe authoritative $(\mathrm{r}=0,608$, $\mathrm{p}<0,01)$ dan berdasarkan Sugiyono (2014) derajat korelasinya kuat. Mindful parenting juga menunjukkan korelasi yang negatif dengan pola asuh tipe authoritrian $(\mathrm{r}=-0,278, \mathrm{p}<0,01)$ dan berdasarkan Sugiyono (2014) nilai korelasinya rendah. Sementara mindful parenting tidak berhubungan dengan pola asuh tipe permissive $(\mathrm{r}=-0,171, \mathrm{p}=$ $0,087)$. Dengan demikian, hasil penelitian ini menunjukkan bahwa hipotesis alternatif 1 dan 2 diterima dan hipotesis alternatif 3 ditolak.

Tabel 3. Hasil korelasi Pearson Product Moment

\begin{tabular}{lcc}
\multicolumn{3}{c}{ Moment } \\
\hline Tipe Pola Asuh & \multicolumn{2}{c}{ Mindfulness in Parenting } \\
& $R$ & Sig (2 Tiled) \\
\hline Authoritative & 0,608 & $0,000^{* *}$ \\
Authoritarian & $-0,278$ & $0,005^{* *}$ \\
Permissive & $-0,171$ & 0,087 \\
\hline
\end{tabular}

Mindful parenting menunjukkan korelasi yang positif, kuat, dan signifikan dengan pola asuh authoritative. Hal ini berarti ibu yang semakin menerapkan mindful parenting dalam pengasuhannya pada anak usia 3-6 tahun akan semakin menunjukkan pola asuh authoritative yang tinggi. Mindful parenting adalah memberikan perhatian kepada anak dan proses pengasuhan dengan menekankan intensitas hubungan, fokus perhatian pada pengalaman yang sedang berlangsung dan tidak menghakimi pengalaman tersebut (Kabat-Zinn dalam Duncan, Coatsworth, \& Greenberg, 2009; dalam McCaffrey, Reitman, \& Black, 2017). Ibu yang memiliki tingkat kesadaran dan perhatian yang tinggi dalam pengalaman interaksinya yang sedang berlangsung dengan anak dan tidak menghakimi akan menyadari sikap apa yang perlu ditunjukkan pada anaknya, menyadari tujuan perilaku pengasuhannya pada saat tersebut dan memberikan penilaian apa adanya. Ibu pun akan dapat menampilkan respon yang sesuai terhadap kebutuhan anak-anaknya saat itu karena dapat mengenali keadaan internal dirinya dan juga memahami emosi yang ditunjukkan anaknya. Ketika ibu dapat menunjukkan respon yang tepat dan tetap memerhatikan kebutuhan emosional dalam interaksi dengan anak, maka ibu secara otomatis menujukkan gaya pengasuhan yang positif yaitu authoritative (seimbang antara respon emosional dan pembentukan sikap tanggung jawab terhadap aturan sosial). Hasil penelitian ini mendukung hasil penelitian yang ditemukan oleh Williams dan Wahler (2010) yang mengatakan bahwa orangtua dengan tipe pola asuh authoritative cenderung memiliki mindfulness yang kuat dan baik dalam mengatasi anak yang memiliki masalah. Mindful parenting memudahkan Ibu untuk menerima apapun perilaku yang ditunjukkan anak dan menghindarkan Ibu dari membuat persepsi dan penilaian terhadap perilaku anaknya. Keadaan ini akan memudahkan Ibu untuk membangun komunikasi yang efektif dengan anak dan membawa keadaan yang berlangsung untuk tujuan pengasuhan yang hendak dicapai. Dengan demikian, mindful parenting membuka jalan bagi Ibu untuk membangun dialog yang lebih positif dengan anaknya yang merupakan inti dari gaya pengasuhan authoritative.

Mindful parenting menunjukkan korelasi yang negatif, rendah, dan signifikan dengan pola asuh authoritarian. Hubungan korelasi yang negatif antara mindful parenting dengan pola asuh authoritarian artinya ketika ibu menerapkan mindful parenting yang tinggi, semakin rendah sikap ibu menunjukkan pengasuhan yang authoritarian yang mana memaksakan kehendak dan tidak mengembangkan 
sikap memahami terhadap kebutuhan emosional anak. Sebab mindful parenting menekankan pada kesadaran dan penerimaan setiap pengalaman pengasuhan dengan anak sementara authoritarian justru tidak mengembangkan kepekaan pada anak. Hasil penelitian ini mendukung penelitian yang dilakukan oleh Williams dan Wahler (2010) yang mengatakan bahwa tipe pola asuh authoritarian memang memiliki hubungan korelasi yang negatif dengan mindful parenting. Singh dkk. (dalam Williams \& Wehler, 2010) mengatakan bahwa mindfulness dalam pengasuhan membangun penerimaan yang tenang dari ibu terhadap perilaku anak tanpa berusahan memaksakan kehendaknya saat kondisi yang belangsung dan hal ini bertentangan dengan makna dan ciri dari pola asuh authoritarian. Tipe pola asuh authoritarian memiliki karakteristik dalam mengajarkan anak dengan aturanaturan yang ketat, dan juga anak diwajibkan untuk mematuhi semua aturan yang dibuat oleh orangtua tanpa adanya kompromi dan pemahaman dari sudut pandang anaknya (Baumrind dalam Robinson, Mandleco, Olsen, \& Hart, 2001). Dengan demikian, semakin orang tua menampilkan mindful parenting yaitu penerimaan tanpa penghakiman dan pemaksaan terhadap anaknya, maka semakin rendah kemungkinan orang tua menggunakan gaya pengasuhan authoritarian.

Pada tipe pola asuh permissive tidak memiliki hubungan yang signifikan dengan mindful parenting. Pola asuh permissive menurut Baumrind (dalam Robinson, Mandleco, Olsen, \& Hart, 2001) merupakan sikap orangtua yang tidak terlibat dalam kehidupan anak. Hal ini berkebalikan dari makna dan praktik mindful parenting. Temuan ini sesuai dengan penelitian Williams dan Wahler (2010) yang mengatakan bahwa mindful parenting dengan tipe pola asuh permissive tidak memiliki hubungan yang signifikan antar keduanya. Penelitian ini juga sesuai dengan temuan Gouveia, Carona, Canavarro, dan Moreira (2016), yang menunjukkan bahwa lebih tinggi tingkat mindful parenting orang tua, maka akan lebih tinggi dalam hal memberikan pengasuhan yang penuh dengan perhatian dan bukan pengabaian.

Kekurangan pada penelitian adalah pada populasi yang menjadi sasaran penelitian. Dalam penelitian ini peneliti hanya fokus pada partisipan ibu yang berdomisili di Jakarta dan ibu yang memiliki anak usia 3-6 tahun. Dengan demikian hasil dari penelitian ini belum bisa untuk digeneralisasikan pada daerahdaerah selain Jakarta atau ibu yang memiliki anak usia lainnya.

\section{SIMPULAN}

Hasil dari penelitian ini menunjukkan bahwa terdapat hubungan positif dan signifikan antara mindful parenting dengan tipe pola asuh authoritative pada ibu yang memiliki anak usia 3-6 tahun. Sementara itu, mindful parenting memiliki hubungan yang negative dan signifikan dengan pola asuh authoritarian dan tidak terdapat hubungan yang signifikan dengan pola asuh permissive. Mindful parenting memiliki derajat hubungan yang kuat denganpola asuh authoritative. Mindful parenting memfasilitasi keadaan internal ibu untuk lebih dapat menyadari keadaan internalnya sehingga juga lebih dapat memperhatikan keadaan yang sedang berlangsung dalam interaksinya dengan anak. Dengan kondisi ini, ibu mengurangi persepsi yang dapat mempengaruhi penilaian terhadap perilaku anak sehingga lebih dapat menerima perilaku anak. Ibu pun dapat memilih untuk menerapkan gaya pengasuhan authoritative, yaitu mengaktifkan dialog dengan anak dalam rangka membuat anak memahami perilaku dan tujuan pengasuhan yang hendak dicapai. Dengan demikian, semakin tinggi kemampuan ibu 
melibatkan mindful parenting dalam berinteraksi dengan anak, ibu semakin dapat menerapkan gaya pengasuhan authoritative.

\section{SARAN}

Saran yang dapat diberikan berdasarkan hasil penelitian ini adalah sebagai berikut:

a. Penelitian ini hanya dilakukan pada ibu dengan anak usia dini sementara tantangan pengasuhan dapat berbeda pada tiap fase usia anak. Oleh karena itu, penelitian selanjutnya dapat dilakukan pada orang tua dengan rentang usia anak yang berbeda.

b. Sampel penelitian ini juga masih bersifat umum sementara pada era saat ini orang tua mengalami perubahan peran sosial. Penelitian berikutnya dapat dilakukan pada ibu yang bekerja, orang tua yang bekerja, orang tua dengan kebutuhan khusus, orang tua dengan anak berkebutuhan khusus, dan sebagainya.

c. Sampel pada penelitian ini merepresentasikan secara umum gaya pengasuhan authoritative bila dilihat dari hasil penilaiannya. Penelitian selanjutnya dapat menggunakan jenis sampel yang mewakili dari tiap gaya pengasuhan.

d. Penelitian dilakukan pada wilayah Jakarta yang merupakan kota besar dan penduduknya hampir dapat dikatakan cukup beragam. Penelitian selanjutnya dapat dilakukan di wilayah lain atau daerah pedesaan yang masih mempertahankan konteks budaya sehingga dapat dianalisis bagaimana kaitan konteks budaya dengan mindful parenting dan gaya pengasuhan.

e. Bagi para praktisi keluarga dan pengasuhan dapat menggiatkan praktik mindfulness dalam pengasuhan terutama pada masa awal-awal kelahiran yang merupakan masa adaptasi bagi ibu dan ayah.
Terutama bagi ibu yang pada masa awal paska kelahiran mengalami penyesuaian yang lebih besar secara fisik dan psikologis dibanding ayah. Hal ini diharapkan menambah kesiapan dan menjaga kesehatan mental ibu dan ayah sehingga dapat menjalin kelekatan secara penuh kesadaran dengan buah hatinya.

\section{DAFTAR PUSTAKA}

Black, M.M, Walker, S.P., Fernald, L.C.H., Anderson, C.T., Digirolama, A.M., Lu, C., DKK. (October, 2016). Early childhood development coming of age: Science through the life course. Series of Advancing Early Childhood Development: from Science to Scale 1. http://dx.doi.org/10.1016/SO140-6736 (16)31389-7

Cooklin, A.R., Giallo, R., Rose, N. (2012). Parental fatigue and parenting practices during early childhood: an Australian community survey. Child: Care, Health, and Development, vol. 38 (5), 654-664, doi:10.1111/j.13652214.2011.01333.x

Duncan, L. G., Coatsworth, J. D., \& Greenberg, M. T. (2009). A Model of Mindful Parenting: Implications for Parent-Child Relationships and Prevention Research. Clinical Child and Family Psychology Review. https://doi.org/10.1007/s10567-0090046-3

Gouveia, M. J., Carona, C., Canavarro, M. C., \& Moreira, H. (2016). SelfCompassion and Dispositional Mindfulness Are Associated with Parenting Styles and Parenting Stress: the Mediating Role of Mindful Parenting. Mindfulness, 7(3), 700-712. https://doi.org/10.1007/s12671-0160507-y

McCaffrey, S., Reitman, D., \& Black, R. (2017). Mindfulness In Parenting Questionnaire (MIPQ): Development and Validation of a Measure of Mindful Parenting. Mindfulness, 8(1), 232-246. https://doi.org/10.1007/s12671-0160596-7

Mubarok, P. P. (2016). Program pengasuhan positif untuk meningkatkan 
keterampilan mindful parenting orangtua remaja. PSYMPATHIC, 3, 3550 .

Parent, J., McKee, L.G., Rough, J.N., \& Forehand, R. (2016). The association of parent mindfulness with parenting and youth psychopathology across three developmental stages. Journal of Abnormal Child Psychology, vol. 44(1),191-202, $\quad$ 10.1007/s10802-0159978-x

Robinson, C. C., Mandleco, B., Olsen, S. F., \& Hart, C. H. (2001). The parenting styles and dimensions questionnaire. Handbook of Family Measurement Techniques: Vol. 3. Instruments \& Index, (November 2016), 319-321. https://doi.org/10.2466/pr0.1995.77.3.81 9

Santrock, J.W. (2015). Life-span development $\left(15^{\text {th }}\right.$ ed.). New York: McGraw-Hill, Inc.

Sigelman, C.K., \& Rider, E.A. (2002). Life span human development $\left(5^{\text {th }} \mathrm{ed}\right.$.). Canada: Thompson Wadsworth.

Sugiyono. (2014). Statistika untuk penelitian. Bandung: Alfabeta

Williams, K. L., \& Wahler, R. G. (2010). Are mindful parents more authoritative and less authoritarian? An analysis of clinicreferred mothers. Journal of Child and Family Studies, 19(2), 230-235. https://doi.org/10.1007/s10826-0099309-3 